\title{
Distribution of Physicochemical Parameters through Soil Profiles around Auto-Mechanic Workshop Clusters in Yenagoa Metropolis, Nigeria
}

\author{
O. Amukali and P.A. Bariweni
}

\section{ABSTRACT}

In this study, results of analyses were carried out on the physicochemical parameters of soils around auto-mechanic workshop clusters and a control site following standard procedures and methodologies within Yenagoa Metropolis for parameters like $\mathrm{pH}$, conductivity, $\mathrm{NO}_{3}, \mathrm{PO}_{4}, \mathrm{SOM}, \mathrm{Ca}, \mathrm{Mg}, \mathrm{Na}, \mathrm{K}, \mathrm{CEC}$ and THC. Values for the parameters were observed, in most instances to have followed the Distance-Decay Model. In such cases, the parameters showed higher levels at the top soils $(0-15 \mathrm{~cm})$ than in lower soil profiles $(15-30 \mathrm{~cm}$ and 30 $45 \mathrm{~cm}$ ) and generally decreased with increasing distances $(50 \mathrm{~m}$ and $100 \mathrm{~m})$ from the reference points $(0 \mathrm{~m})$ at the auto-mechanic workshop clusters, depending on influencing factors. At the auto-mechanic workshop clusters, $\mathrm{pH}$ varied from 6.0 to 6.8 indicating acidification of soils, conductivity varied from 594 to $10,258.20$ úS/cm, nitrates from 3.3 to $4.6 \mathrm{mg} / \mathrm{kg}$, phosphates from 0.4 to $0.6 \mathrm{mg} / \mathrm{kg}$, SOM from 4.4 to6.0\% and calcium from 11.4 to $26.7 \mathrm{meq} / 100 \mathrm{~g}$. Others were magnesium from 4.8 to $9.2 \mathrm{meq} / 100 \mathrm{~g}$, sodium from 6.7 to $17.5 \mathrm{meq} / 100 \mathrm{~g}$, potassium from 3.5 to $5.1 \mathrm{meq} / 100 \mathrm{~g}$, CEC from 26.5 to $44.9 \mathrm{meq} / 100 \mathrm{~g}$ and THC from 4.5 to $5.4 \mathrm{mg} / \mathrm{kg}$ respectively. Thus, it could be safely stated that operational presence of auto-mechanic workshop clusters did impact the physicochemical parameters of soils within closer vicinities as topsoils $(0-15 \mathrm{~cm})$ and reference points $(0 \mathrm{~m})$ more significantly than soils farther away from their vicinities. This raises health, environmental and food productivity concerns in soils of the study area.

Keywords:Auto-mechanic workshop clusters, physicochemical parameters, spatial distribution

\section{INTRODUCTION}

According to [13] soil refers to a natural body, synthesized in profile form from a variable mixture of broken and weathered minerals and decayed organic matter, which covers the earth in a thin layer and which supplies, when containing the amount of air and water, mechanical support and imparts sustenance for plants. Simply put, soils are the solid parts of the earth upon which plants grow, naturally and upon which many developmental projects are sited. It generally supports the growth of plants [17].

Increasing global human population has necessitated the need for sophistications and increase in automobiles to help make man move faster, produce more efficiently and faster and harvest in a much timely manner [7]. These necessitated the need for citing more auto-mechanic workshop clusters in major towns to help in repair and servicing of these automobiles. However, wastes generated by artisans from repair and servicing works do impact soil physicochemical parameters in a number of ways as soil physicochemical parameters are important factors for assessing soil fertility and mobility of ions in soils. $\mathrm{pH}$ is a measure of hydrogen ions concentration of a given media, thus, a measure of the level of acidity or alkalinity of a given substance. $\mathrm{pH}$ values that are outside ranges favourable to the sustenance of given organisms would induce considerably high environmental stress on such organism's physical systems and their tendencies to reproduce naturally and could lead to a significant reduction in biodiversity within such ecosystems. Thermal conductivity is key to knowing the mass and energy exchange processes in the soil-atmospheric system [5]. For instance, Ibid [5] investigated the relationship between thermal conductivity and some chemical compositions of the soils from the Niger Delta region of Nigeria and they did establish that thermal conductivity did affect some vital soil chemical components. Nitrates play vital roles in enhancing soil fertility and productivity. They enhance vegetative growth of plants and help give plants their characteristic luxuriant greenish growths. Phosphates could be found naturally in soils and they play vital roles in enhancing fruit development and ripening.Organic matter plays vital roles in metal binding capacity of soils [4] and thus influences fertility of soils, contributes to enhancing crop yields and the mobility of heavy metals. Cation exchange capacity is the amount of exchangeable cation per unit weight of dry soil that plays an important role in soil fertility [6] while Total Petroleum Hydrocarbon (TPH) could be introduced into soil systems naturally or 
artificially. CEC could also affect heavy metal distribution in soils [20]

Generally, the Distance-Decay Model is a geographical term that describes the effect of distance on spatial interactions and through this concept, variations in soil physicochemical parameters within and around soils of auto-mechanic workshop clusters were explained in this study. Thus, differences in physicochemical values over soil profiles $(0-15 \mathrm{~cm}, 15-30 \mathrm{~cm}$ and $30-45 \mathrm{~cm})$ and distances $(0 \mathrm{~m}, 50 \mathrm{~m}$ and $100 \mathrm{~m})$ were explained using this concept. Reference [22] did stress the importance of Distance-Decay Model on similarity in ecological theory and biodiversity conservation. However, there are currently few studies detailing the distributional patterns of physicochemical parameters of soils within and around auto-mechanic workshop clusters in Yenagoa Metropolis with special reference to depth-wise distribution and distance-wise distribution, respectively. This formed the basis of this work.

\section{MATERIALS AND METHODS}

\section{A. Study Area}

Yenagoa Metropolis is the Capital of Bayelsa State, Nigeria (Figure 1). It occupies an estimated area of $706 \mathrm{~km}^{2}$ [30]. The population of Yenagoa Local Government Area was estimated to be 353,344 people in 2006 , comprising 187,791 males and 165,553 females with an annual exponential growth rate of $2.9 \%$ [16]. It is located between latitudes $4^{\circ} 50^{\prime} \mathrm{N}$ and $5^{\circ} 05^{\prime} \mathrm{N}$ and longitudes $6^{\circ} 15^{\prime} \mathrm{E}$ and $6^{\circ} 30^{\prime} \mathrm{E}$ and lies astride the Epie Creek which empties into the Ekole Creek [9].

According to [28], the soils of Yenagoa metropolis were principally classified as rain forest soils and these rainforest soils were characterized to have constituted of over $90 \%$ of the soils to be belonging to the following Orders; Entisols, Oxisols and Alfisols. Ibid [28] further stated that the soils were mainly loamy at the topsoil and sandy clay loam at the mid-depth and bottom soil profiles, respectively. In another dimension, [6] described the study area to be located in a humid tropical wetland area with mean annual rainfall of about $2539 \mathrm{~mm}$ with an average mean temperature of $26.2^{\circ} \mathrm{C}$ while [28] further stated that rainfall within the study area was throughout the year with peaks from June to September and relative humidity was usually about $85 \%$ in the wet season and $45 \%$ in the dry season

According to reference [23], vegetation of the study area fell under the fresh water swamp forest, comprising thick tall and thick shady trees, climbers, shrubs and grasses as well as other economic trees like Raffia palm, oil palm trees, Wild/African Mango and Crocuces. In addition, [28] stated that the study area constituted of farmlands, fallows and sparse vegetation. Also, [8] in their work on wetland cover changes in Yenagoa metropolis used remotely accessed imageries for 1987, 2002 and 2015 to establish that the study area is located within a massive wetland whose quantitative extent is seriously being lost developmental tendencies occasioned by urbanization.

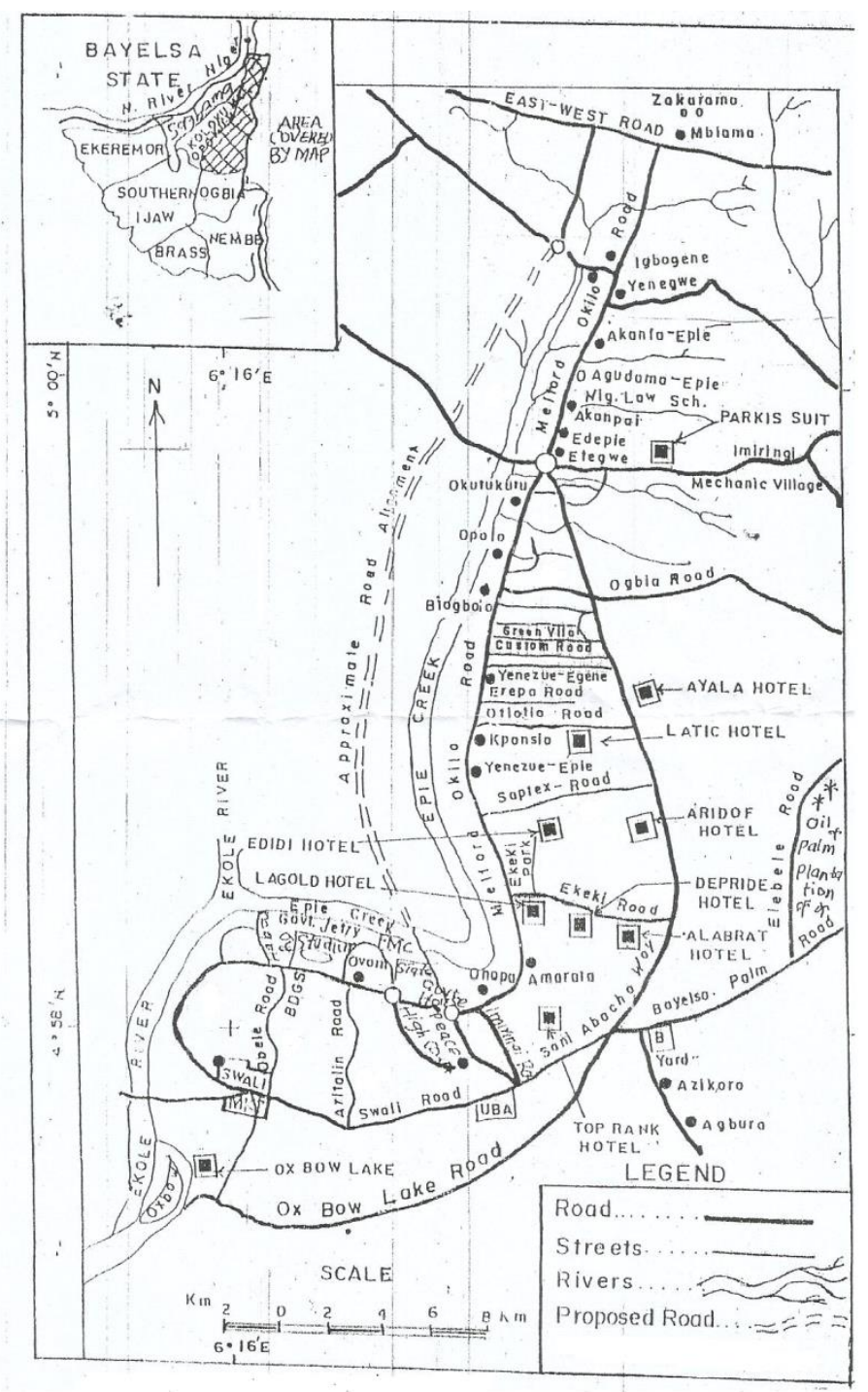

Fig. 1. Map of Yenagoa Metropolis showing sampled sites. Source: Agusomu (2005).

\section{B. Sampling Design}

Simple random sampling was employed during soil sampling. Samples were taken by throwing a quadrant measuring $1 \mathrm{~m} \times 1 \mathrm{~m}$ within the vicinity of the auto-mechanic workshop clusters and this was considered the reference point $(0 \mathrm{~m})$ as used by [7]. From there, a meter rule was drawn $50 \mathrm{~m}$ and $100 \mathrm{~m}$ away from the reference point $(0 \mathrm{~m})$ and soil samples were collected. The samples were collected over three months each for dry and wet seasons and mean values of both seasons were taken to cancel out seasonal effects. Samples were collected within and around automechanic workshop clusters at Imiringi, Igbogene, Swali, Imgbi, Etegwe communities as well as a control site which was an uncultivated forestland at Zarama-Igbogene bypass road as this area was observed to be free from anthropogenic activities.

The sample population was 12 auto-mechanic workshop clusters enumerated within the study area as field survey showed that there was one auto-mechanic village and eleven auto-mechanic workshop clusters in the study area. These consisted of 1 auto-mechanic workshop village at Imiringi and 11 auto-mechanic workshop clusters at Imgbi, Igbogene, Swali, Etegwe, Opolo, Kpansia, Sani Abacha 
Expressway, AgudamaEpie, Onopa, Edepie and Ovom respectively.

\section{Methods of Soil Sample Collection}

Soil samples were collected following standard procedures and methodologies from 3 different soil depths; $0-15 \mathrm{~cm}, 15-30 \mathrm{~cm}$ and $30-45 \mathrm{~cm}$ and distances, $0 \mathrm{~m}, 50 \mathrm{~m}$ and $100 \mathrm{~m}$, respectively as adopted from the works of $[24$, 25]. These were done in 6 distinct sites; 5 auto-mechanic workshop clusters and a control site. Homogeneous mixtures were made from the collected soil samples and homogenized samples were carefully put into aluminiumfoil papers to prevent effects of the vagaries of weather, tied up and labeled appropriately before being taken to the laboratory for analysis as done by [7].

\section{Methods of Soil Sample Digestion, Preparation and Laboratory Analysis of physicochemical Analysis}

The standard method of USEPA 3052 [29] was adopted for sample digestion in this study while the APHA 460 electrometric method described by [26] was used for determining soil $\mathrm{pH}$. The ASTMD 1125 method as recommended by [15] was used for determining conductivity while the ASTM D 3867 standard method as used by [9] was adopted for determination of nitrates in this study. The APHA 425C standard method by [11] for the determination of phosphate levels in soils was adopted for determination of phosphate levels in this study.

Furthermore, the EPA titrimetric method [29]was adopted for CEC determination in this work. Through this method, the concentrations of potassium, sodium, calcium and magnesium in the soil samples were determined. Soil organic matter was determined through the ASTM D 2579 method as described by [12]. Finally, the total extractable hydrocarbon content was determined through the ASTM D 3921 Infra Red Spectrophotometric method as recommended by [15].

\section{E. Statistical Analysis}

Descriptive statistics with mean using the least significant difference (LSD) for unequal replications were calculated according to the method used by [18]. The levels of significance were determined at $\alpha=0.05$ [10]. Calculations were done using Excel Spread sheet for doing simple mean, standard deviation and Pearson Correlation Coefficients and these were used to interpret the results. Results were then represented in Tabular forms with final depicted results in Table 1 being the overall mean from all values from the auto-mechanic workshop clusters and the control site.

\section{RESUlts AND Discussion}

Results in Figure 2 showed that $\mathrm{pH}$ in soils of automechanic workshop clusters in Yenagoa Metropolis were observed to be weakly acidic as compared to soils taken from the control sites which were all strongly alkaline. Levels of soil alkalinity in soils at the control site were not significantly different over distance and soil depths while on the other hand, soil acidity didn't still show any net significant difference with respect to soil depths and distances, except in samples taken $50 \mathrm{~m}$ away from the automechanic workshop clusters (Table 1). The relatively stable $\mathrm{pH}$ levels in soils taken from the control site could be due to the absence of impactful anthropogenic activities within the area. Specifically, mean values of $\mathrm{pH}$ in this study revealed that soil acidity decreased slightly with increasing soil depths in soil samples encountered $50 \mathrm{~m}$ away from the reference point $(0 \mathrm{~m})$ of the auto-mechanic workshop clusters but fairly constant in soil samples encountered $100 \mathrm{~m}$ away and at the reference point $(0 \mathrm{~m})$, except in samples taken $30-45 \mathrm{~cm}$ depths. Soil mineral components and conductivity could be responsible for this scenario [2].

Table 1: Distribution of Physicochemical Parameters in Soils of Yenagoa Metropolis and Control

\begin{tabular}{|c|c|c|c|c|c|c|c|c|c|c|}
\hline \multirow{2}{*}{ Parameters } & \multirow{2}{*}{$\begin{array}{c}\text { Distances } \\
\text { Depths } \\
\end{array}$} & \multicolumn{3}{|c|}{0 meter } & \multicolumn{3}{|c|}{50 meters } & \multicolumn{3}{|c|}{100 meters } \\
\hline & & $0-15$ & $15-30$ & $30-45$ & $0-15$ & $15-30$ & $30-45$ & $0-15$ & $15-30$ & $30-45$ \\
\hline \multirow{2}{*}{$\mathrm{pH}$} & $\mathrm{X} \pm \mathrm{STD}$ & $6.8 \pm 0.5$ & $6.8 \pm 0.6$ & $6.6 \pm 0.5$ & $6.2 \pm 1.0$ & $6.8 \pm 1.0$ & $6.9 \pm 1.1$ & $6.0 \pm 1.1$ & $6.0 \pm 1.0$ & $6.0 \pm 0.9$ \\
\hline & Control & $7.1 \pm 0.1$ & $7.1 \pm 0.1$ & $7.1 \pm 0.1$ & $7.1 \pm 0.0$ & $7.1 \pm 0.0$ & $7.1 \pm 0.0$ & $7.2 \pm 0.0$ & $7.1 \pm 0.0$ & $7.1 \pm 0.0$ \\
\hline \multirow{2}{*}{ Conductivity } & $\mathrm{X} \pm \mathrm{STD}$ & $\begin{array}{c}10,258.2 \pm \\
8,995.0\end{array}$ & $\begin{array}{c}5,914.4 \pm \\
5,926.5 \\
\end{array}$ & $\begin{array}{c}6,287.1 \pm \\
7,963.8 \\
\end{array}$ & $\begin{array}{c}2,710.0 \pm \\
1,492.0\end{array}$ & $\begin{array}{c}1,214.2 \pm \\
643.1\end{array}$ & $\begin{array}{c}954.0 \pm \\
523.9\end{array}$ & $\begin{array}{c}4,566.1 \pm \\
4,560.0\end{array}$ & $\begin{array}{c}1,006.3 \pm \\
770.5 \\
\end{array}$ & $\begin{array}{c}834.2 \pm \\
688.7\end{array}$ \\
\hline & Control & $\begin{array}{c}11,083 \pm \\
1,109.5 \\
\end{array}$ & $\begin{array}{l}9,643 \pm \\
1,109.5\end{array}$ & $\begin{array}{l}7,775 \pm \\
1,109.8\end{array}$ & $\begin{array}{l}6,775 \pm \\
1,174.6\end{array}$ & $\begin{array}{l}3,391 \pm \\
1,174.3\end{array}$ & $\begin{array}{l}2,106 \pm \\
1,174.4 \\
\end{array}$ & $\begin{array}{c}1,286 \pm \\
993.3 \\
\end{array}$ & $\begin{array}{l}961 \pm \\
993.0\end{array}$ & $\begin{array}{l}843 \pm \\
993.3\end{array}$ \\
\hline \multirow{2}{*}{ Nitrates } & $\mathrm{X} \pm \mathrm{STD}$ & $4.6 \pm 1.2$ & $4.2 \pm 1.5$ & $4.0 \pm 1.3$ & $4.3 \pm 1.7$ & $4.3 \pm 1.7$ & $4.2 \pm 1.7$ & $3.4 \pm 1.4$ & $3.3 \pm 1.5$ & $3.6 \pm 1.6$ \\
\hline & Control & $4.0 \pm 0.2$ & $3.8 \pm 0.2$ & $3.7 \pm 0.2$ & $2.9 \pm 0.2$ & $2.8 \pm 0.2$ & $2.4 \pm 0.2$ & $2.2 \pm 0.2$ & $2.0 \pm 0.2$ & $2.0 \pm 0.2$ \\
\hline \multirow{2}{*}{ Phosphates } & $\mathrm{X} \pm \mathrm{STD}$ & $0.5 \pm 0.1$ & $0.5 \pm 0.2$ & $0.5 \pm 0.2$ & $0.6 \pm 0.1$ & $0.5 \pm 0.1$ & $0.5 \pm 0.2$ & $0.4 \pm 0.1$ & $0.4 \pm 0.1$ & $0.4 \pm 0.1$ \\
\hline & Control & $0.3 \pm 0.0$ & $0.4 \pm 0.0$ & $0.4 \pm 0.0$ & $0.3 \pm 0.0$ & $0.3 \pm 0.0$ & $0.3 \pm 0.0$ & $0.3 \pm 0.0$ & $0.3 \pm 0.0$ & $0.2 \pm 0.0$ \\
\hline \multirow{2}{*}{ SOM } & $\mathrm{X} \pm \mathrm{STD}$ & $6.0 \pm 0.6$ & $5.8 \pm 0.5$ & $5.5 \pm 0.3$ & $5.8 \pm 0.5$ & $5.4 \pm 0.9$ & $5.5 \pm 0.9$ & $4.7 \pm 0.3$ & $4.4 \pm 0.3$ & $4.8 \pm 0.2$ \\
\hline & Control & $6.8 \pm 0.2$ & $7.0 \pm 0.2$ & $7.4 \pm 0.2$ & $5.2 \pm 0.3$ & $5.4 \pm 0.4$ & $6.2 \pm 0.3$ & $4.6 \pm 0.4$ & $5.0 \pm 0.4$ & $5.5 \pm 0.4$ \\
\hline \multirow{2}{*}{ Calcium } & $\mathrm{X} \pm \mathrm{STD}$ & $26.7 \pm 12.1$ & $21.6 \pm 9.4$ & $21.6 \pm 11.6$ & $16.6 \pm 3.5$ & $15.5 \pm 2.7$ & $14.7 \pm 2.7$ & $17.0 \pm 7.9$ & $12.7 \pm 3.7$ & $11.4 \pm 2.7$ \\
\hline & Control & $35.7 \pm 1.8$ & $34.2 \pm 1.8$ & $34.0 \pm 1.8$ & $28.9 \pm 1.8$ & $27.3 \pm 1.8$ & $27.1 \pm 1.8$ & $19.5 \pm 1.8$ & $18.6 \pm 1.8$ & $18.4 \pm 1.8$ \\
\hline \multirow{2}{*}{ Magnesium } & $\mathrm{X} \pm \mathrm{STD}$ & $9.2 \pm 3.5$ & $6.4 \pm 2.3$ & $6.6 \pm 2.6$ & $5.1 \pm 1.0$ & $5.1 \pm 0.6$ & $4.9 \pm 0.8$ & $7.3 \pm 3.4$ & $5.3 \pm 1.1$ & $4.8 \pm 1.1$ \\
\hline & Control & $4.9 \pm 0.1$ & $4.6 \pm 0.2$ & $4.6 \pm 0.2$ & $5.3 \pm 0.1$ & $5.2 \pm 0.1$ & $5.2 \pm 0.1$ & $6.4 \pm 0.1$ & $5.3 \pm 0.1$ & $5.3 \pm 0.1$ \\
\hline \multirow[t]{2}{*}{ Sodium } & $\mathrm{X} \pm \mathrm{STD}$ & $17.5 \pm 8.5$ & $12.9 \pm 6.3$ & $11.9 \pm 6.0$ & $9.7 \pm 2.6$ & $8.7 \pm 0.8$ & $7.7 \pm 1.0$ & $10.1 \pm 5.5$ & $7.6 \pm 2.3$ & $6.7 \pm 1.9$ \\
\hline & Control & $21.2 \pm 1.1$ & $18.2 \pm 1.1$ & $14.5 \pm 1.1$ & $17.1 \pm 1.0$ & $14.0 \pm 1.0$ & $11.3 \pm 1.0$ & $11.5 \pm 0.7$ & $9.3 \pm 0.7$ & $8.9 \pm 0.7$ \\
\hline \multirow[t]{2}{*}{ Potassium } & $\mathrm{X} \pm \mathrm{STD}$ & $5.1 \pm 1.6$ & $4.6 \pm 1.5$ & $5.1 \pm 2.1$ & $4.2 \pm 0.7$ & $4.0 \pm 0.3$ & $3.6 \pm 0.5$ & $5.1 \pm 2.7$ & $3.8 \pm 0.6$ & $3.5 \pm 0.5$ \\
\hline & Control & $5.2 \pm 0.2$ & $4.9 \pm 0.2$ & $4.4 \pm 0.2$ & $4.7 \pm 0.2$ & $4.1 \pm 0.2$ & $4.0 \pm 0.2$ & $3.9 \pm 0.1$ & $3.5 \pm 0.1$ & $3.3 \pm 0.1$ \\
\hline \multirow[t]{2}{*}{ CEC } & $\mathrm{X} \pm \mathrm{STD}$ & $57.4 \pm 25.0$ & $44.9 \pm 18.3$ & $45.2 \pm 22.1$ & $35.6 \pm 7.0$ & $33.2 \pm 4.0$ & $30.9 \pm 4.4$ & $39.6 \pm 19.2$ & $29.4 \pm 7.4$ & $26.5 \pm 5.6$ \\
\hline & Control & $67.1 \pm 2.9$ & $61.9 \pm 2.9$ & $57.5 \pm 2.9$ & $56.0 \pm 2.9$ & $50.6 \pm 2.9$ & $47.5 \pm 2.9$ & $41.3 \pm 2.5$ & $36.7 \pm 2.5$ & $35.8 \pm 2.5$ \\
\hline \multirow[t]{2}{*}{ THC } & $\mathrm{X} \pm \mathrm{STD}$ & $5.4 \pm 0.9$ & $5.3 \pm 0.7$ & $5.2 \pm 0.8$ & $4.7 \pm 0.4$ & $5.4 \pm 0.8$ & $5.0 \pm 0.5$ & $4.6 \pm 0.4$ & $4.6 \pm 0.6$ & $4.5 \pm 0.3$ \\
\hline & Control & $3.8 \pm 0.1$ & $3.3 \pm 0.1$ & $3.2 \pm 0.1$ & $3.4 \pm 0.0$ & $3.3 \pm 0.0$ & $3.2 \pm 0.0$ & $3.2 \pm 0.0$ & $3.2 \pm 0.0$ & $3.1 \pm 0.0$ \\
\hline
\end{tabular}


Discharge of waste substances with propensities to cause dilution must have been responsible for higher acidity levels at the auto-mechanic workshop clusters as compared to similar soil samples encountered at the control sites for all distances $(0 \mathrm{~m}, 50 \mathrm{~m} \& 100 \mathrm{~m})$ considered in this study (Fig. 2). Considerably, higher acidity levels in soil samples taken $100 \mathrm{~m}$ away from the auto-mechanic workshop clusters in this present study (Table 1) could have been due to heavy metal mobility $[6,21]$.

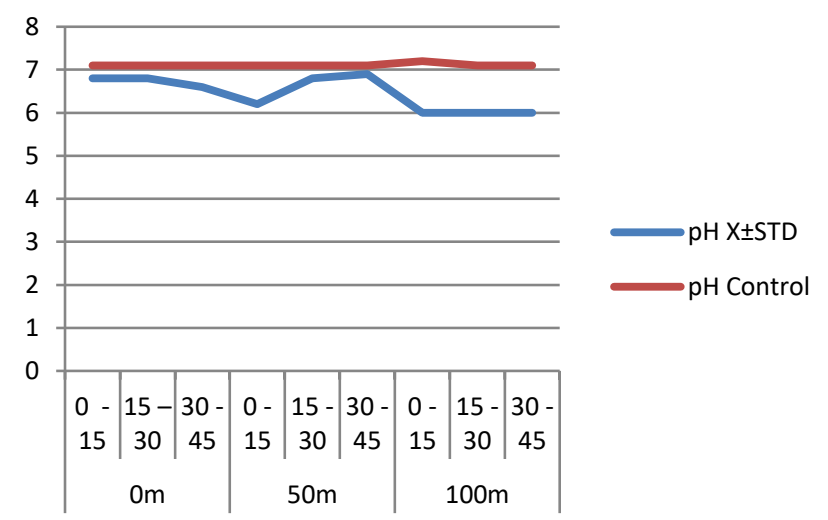

Fig. 2. $\mathrm{pH}$ levels across depths in soils around auto-mechanic workshops in Yenagoa Metropolis.

The values of $\mathrm{pH}$ obtained in this study were consistent with values obtained in other similar studies in Nigeria [24, 25]. Findings in this work were consistent with the work of [18] who observed that a decrease in soil $\mathrm{pH}$ led to a corresponding increase in the mobility of positively charged heavy metals because of proton competition with heavy metals and such led to a decrease in negatively chargedbinding sites. In another instance, [25] did also state that moderately acidic soils as in this present study, do enhance cationic movements from surface to underlying soils, though at a slow rate while [27] succinctly stated that descending $\mathrm{pH}$ is an indication of acidification of soils. Thus, the value of soil $\mathrm{pH}$ in this study has shown that anthropogenic influences resulting from the operational presence of auto-mechanic workshop had to some extent influenced acidification of vulnerable soils.

A general decrease in overall mean conductivity in soils of the study area was observed to occur with increasing soil depths for $0 \mathrm{~m}$ and $50 \mathrm{~m}$ distances at both the auto-mechanic workshop clusters and control sites with soil conductivity at the control site generally having higher values (Fig. 3). Infiltration of solute leachates that originated from wastes from the auto-mechanic workshop clusters must have caused a reduction in conductivity levels in soils of the automechanic workshop clusters as compared to the soils from the control site (Table 1).

In addition, the higher values of conductivity generally noticed at the reference point $(0 \mathrm{~m})$ and $50 \mathrm{~m}$ away as compared the conductivity levels noticed $100 \mathrm{~m}$ in this study could be due to distance decay. Higher influences of anthropogenic activities at closer proximities $0 \mathrm{~m}$ and $50 \mathrm{~m}$ distances must have been responsible for this scenario. This finding agreed with the finding of [31]. Furthermore, at a distance of $100 \mathrm{~m}$ away, where the influences waned-down, conductivity values at the auto-mechanic workshop clusters became higher than values at the control site. Localized soil conditions must have influenced this scenario. On the whole, overall mean concentrations of conductivity in soils of both the auto-mechanic workshop clusters and the control site were observed to have decreased steadily from the topsoil $(0-15 \mathrm{~cm})$ to subsoils $(15-30 \mathrm{~cm} \& 30-45 \mathrm{~cm})$ at all distances considered in this study. Soil moisture content must have played significant solute dilution roles in influencing the variations observed in soils at the various distances. This also goes to show that topsoils are more vulnerable to impacts of anthropogenic activities than subsoils.

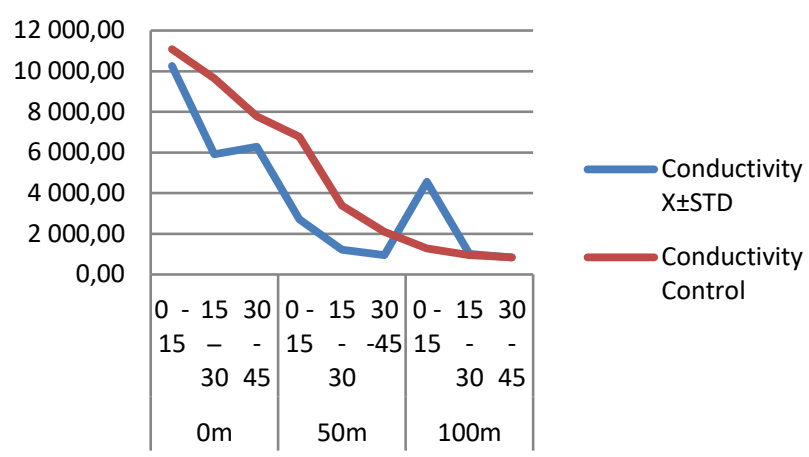

Fig. 3. Conductivity levels across depths in soils around auto-mechanic workshops in Yenagoa Metropolis.

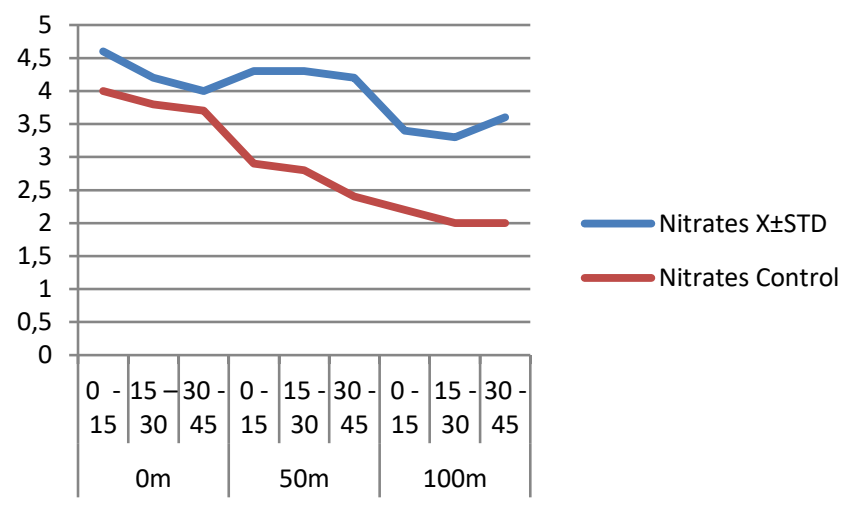

Fig. 4. Nitrate levels across depths in soils around auto-mechanic workshops in Yenagoa Metropolis.

From Table 1, it was observed that mean concentration of nitrate decreased generally with soil depths $(0-15 \mathrm{~cm}, 15-$ $30 \mathrm{~cm} \& 30-45 \mathrm{~cm})$ and distances $(0 \mathrm{~m}, 50 \mathrm{~m} \& 100 \mathrm{~m})$ at both the auto-mechanic workshop clusters and the control sites, respectively. Higher impacts of anthropogenic activities must have influenced higher values of nitrates at the reference points $(0 \mathrm{~m})$ of the auto-mechanic workshop clusters as compared to soil samples encountered $50 \mathrm{~m}$ and $100 \mathrm{~m}$ away from the reference points of the auto-mechanic workshop clusters. This was found to be consistent with the works of [1], [19]. However, higher mean concentrations of nitrates in soils closer to the auto-mechanic workshop cluster but lower in distances farther away or lower soil profiles showed indications of the impact of distance-decay effect.

The fairly higher levels of phosphate over depths and distances in soils of the auto-mechanic workshop clusters as compared to that of the control site was an indication of relatively higher anthropogenic impacts in soils of the study 
area (Figure 5). Thus, it could be safely stated within this context that operational presence of auto-mechanic workshops in the study area must have also impacted on the levels of phosphates.

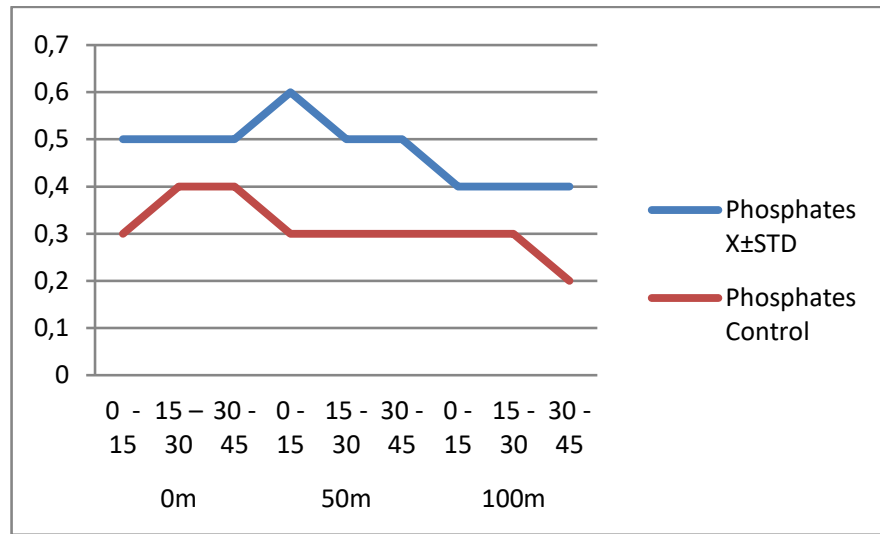

Fig. 5. Phosphate levels across depths in soils around auto-mechanic workshops in Yenagoa Metropolis

From Table 1, it was observed that apart from topsoils (0 $-15 \mathrm{~cm})$ and midsoils $(15-30 \mathrm{~cm})$ sampled $50 \mathrm{~m}$ away from the reference point $(0 \mathrm{~m})$, that the levels of soil organic matter were generally higher in soils at the control site as compared tothose of the auto-mechanic workshop clusters. This implied that discharge of waste materials at the automechanic workshop clusters negative affected soil organic matter content either at the reference point $(0 \mathrm{~m})$ or at $100 \mathrm{~m}$, as affected by runoff at the study area. In addition, soil organic matter was observed to have increased with increasing soil depths at the control site but maintained contrasting trends at the auto-mechanic workshop clusters (Fig. 6).

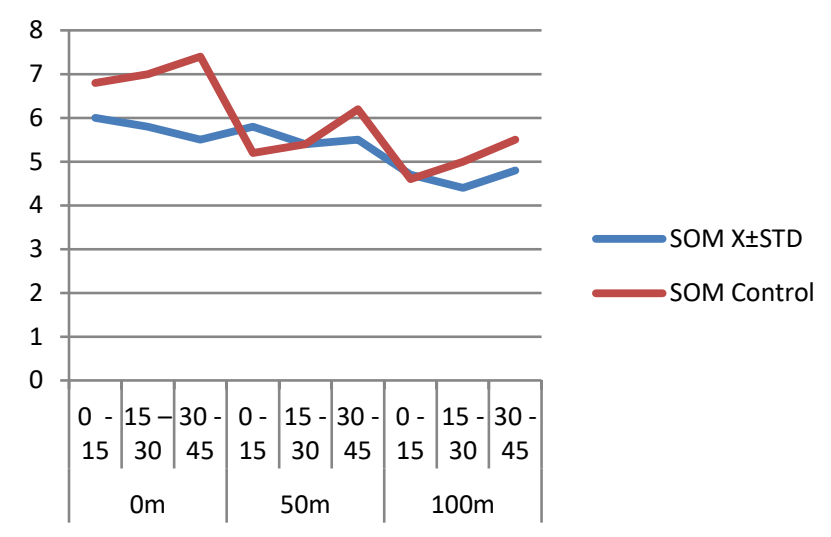

Fig. 6. SOM levels across depths in soils around auto-mechanic workshops in Yenagoa Metropolis

The scenario observed in this study was found to be consistent with the work of [25]. These could be attributable to same impacts of anthropogenic activities in soils at the auto-mechanic workshop clusters and partly due to run-off which must have helped in randomly redistribution waste substances under the influences of topography, climatic conditions, soil particle size distributions as well as frequency distribution of plants as these plants utilize soil organic matter for normal physiologic and metabolic activities.
Generally, distance decay phenomenon was observed to have manifested conspicuously with respect to calcium levels in the study area as mean concentrations of calcium were observed to have steadily decreased with increasing soil depths and distances at both the auto-mechanic workshop clusters and the control site (Figure 7). On the other hand, mean concentrations of calcium were observed to be higher at the control site as compared to soils at the auto-mechanic workshop clusters (Table 1). This is indicative of the negative impacts of anthropogenicity on calcium contents in soils of the auto-mechanic workshop clusters as overall mean concentration of calcium were generally highest at the topsoils $(0-15 \mathrm{~cm})$, lower at the midsoils $(15-30 \mathrm{~cm})$ and lowest at the subsoils (30 $45 \mathrm{~cm}$ ), respectively. This observed characteristic trend could be attributable to the impacts of run-off in helping to enhance redistribution of calcium molecules from the reference point $(0 \mathrm{~m})$ to adjoining $50 \mathrm{~m}$ and $100 \mathrm{~m}$ away from the auto-mechanic workshop clusters.

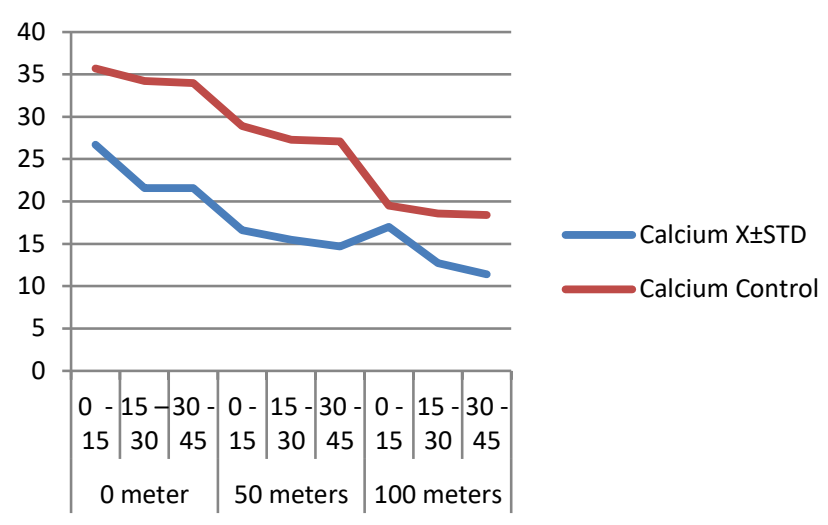

Fig. 7. Calcium levels across depths in soils around auto-mechanic workshops in Yenagoa Metropolis.

From Table 1, it was noted that there were no significant differences in the distributional levels of magnesium over soil depths at the control site, although, they did vary significantly with distances at $5 \%$ level of significance. However, there were higher magnesium content in soils sampled within the reference point $(0 \mathrm{~m})$ at the automechanic workshop clusters as compared to soils at the control site but those sampled $50 \mathrm{~m}$ and $100 \mathrm{~m}$ away generally showed contrasting patterns of distribution when soils of the auto-mechanic workshop and control site were compared (Figure 8). This implied significant impacts of anthropogenic activities like dissolved substances and varying soil organic matter content on enhancement of magnesium deposition in soils at the reference point $(0 \mathrm{~m})$ of the auto-mechanic workshop clusters; though, these effects were felt less in soil that were encountered $50 \mathrm{~m}$ and $100 \mathrm{~m}$ away, respectively.

Mean values of sodium (Fig. 9) and potassium (Fig.10) were observed to have decreased with increasing soil depths and with distances in soils at the auto-mechanic workshop clusters and at the control site, except in subsoils encountered $(30-45 \mathrm{~cm})$ at the reference point $(0 \mathrm{~m})$ of the auto-mechanic workshop clusters. Values for Sodium showed considerably higher levels in soils at the control site as compared to values at the auto-mechanic workshop clusters. This is indicative of existence and predominance of 
sodium-impacting soil conditions at the auto-mechanic workshop clusters in soils at the auto-mechanic workshop clusters. Run-off must have positively influenced the distance decay phenomenon observed with respect to sodium content in soils of both the auto-mechanic workshop clusters and the control site.

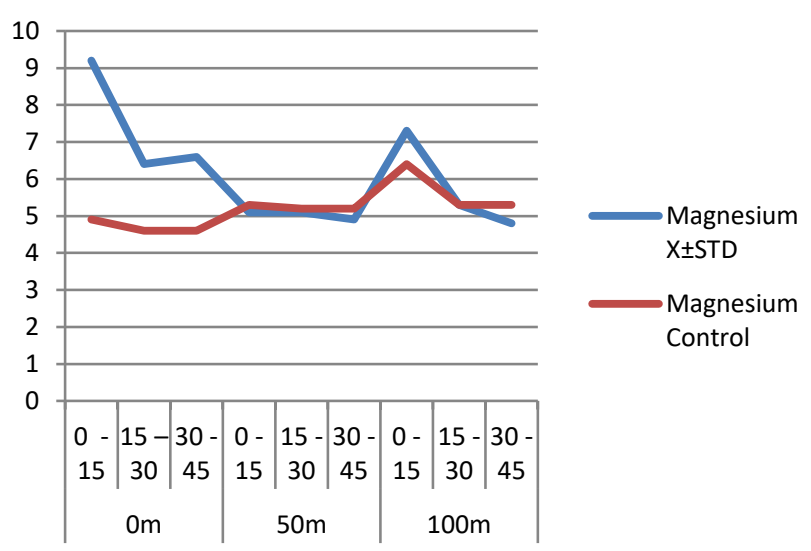

Fig. 8. Magnesium levels across depths in soils around auto-mechanic workshops in Yenagoa Metropolis.

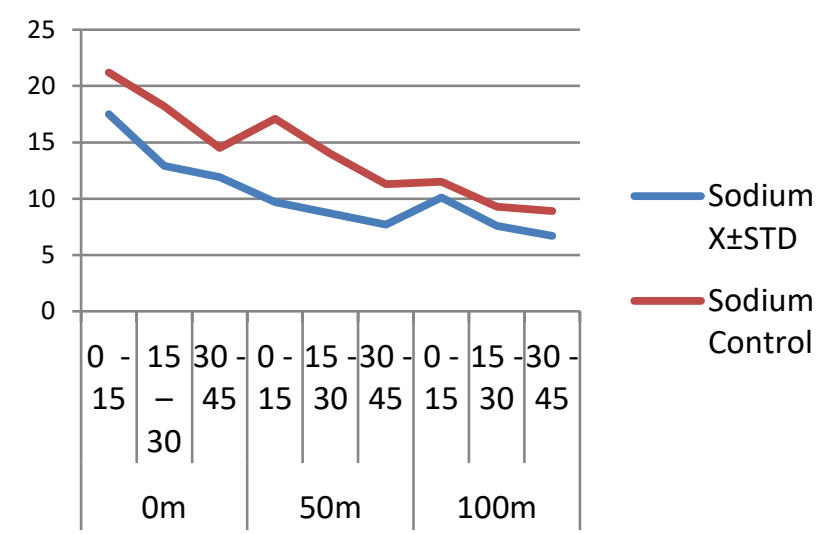

Fig. 9. Sodium levels across depths in soils around auto-mechanic workshops in Yenagoa Metropolis.

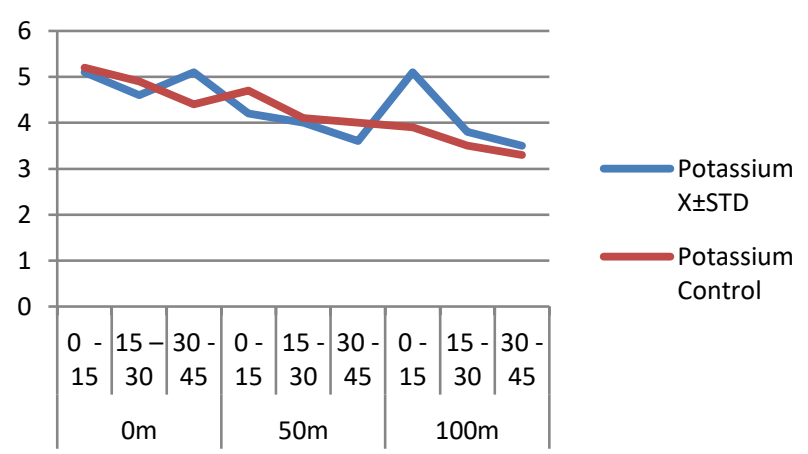

Fig. 10. Potassium levels across depths in soils around auto-mechanic workshops in Yenagoa Metropolis.

Reference [25] earlier stated that cation exchange capacity help in the regulation of the mobility of metals in soils and also increases as the soil $\mathrm{pH}$ increases. Cation exchange capacity has to do with the exchangeable cations involved in a given soil reaction. It is known that cation exchange capacity (CEC) is a measure of the cumulative effects of calcium, magnesium, sodium and potassium, respectively.

It was observed in this study that the overall mean concentration of CEC in soils at the control site and the auto-mechanic workshop clusters generally deceased with increasing soil depths over respective distances $(0 \mathrm{~m}, 50 \mathrm{~m} \&$ $100 \mathrm{~m})$, with the exception of subsoils $(30-45 \mathrm{~cm})$ at the reference point $(0 \mathrm{~m})$ of the auto-mechanic workshop clusters (Table 1). In addition, it was further observed that CEC was fairly higher in soils at the control site as compared to soils at the auto-mechanic workshop clusters (Fig. 10). This implied that CEC in soils at the automechanic workshop clusters was to some extent, negatively affected by anthropogenic activities, when compared with results recorded at the control site.

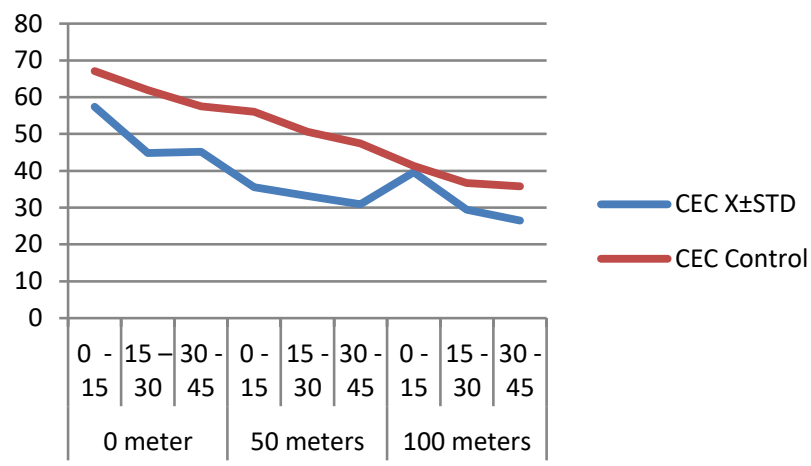

Fig. 11. CEC levels across depths in soils around auto-mechanic workshops in Yenagoa Metropolis.

At the control site, total hydrocarbon carbon (THC) gradually decreased with increasing soil depths and with distances as could be seen from Fig. 12. Higher levels of THC was noticed at the reference point $(0 \mathrm{~m})$ at the automechanic workshop clusters and the control site, signifying significant input of THC into soils of the study area throughanthropogenic influences.

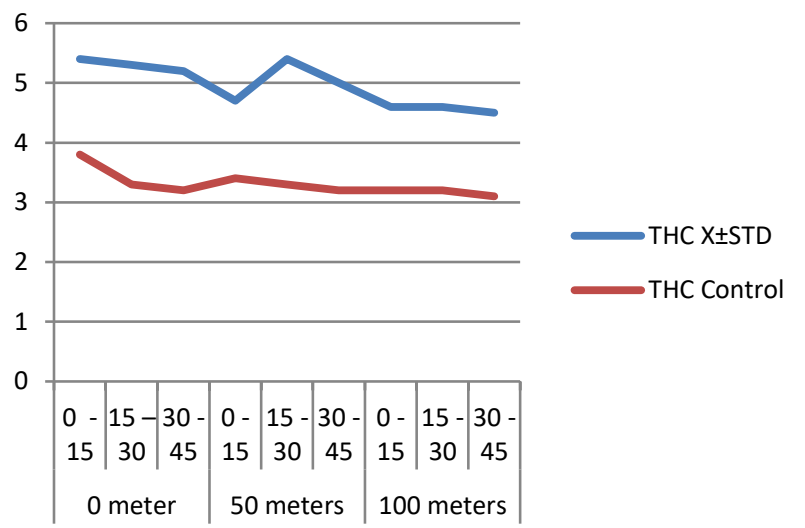

Fig. 12. THC levels across depths in soils around auto-mechanic workshops in Yenagoa Metropolis.

Lower levels of THC in soils sampled $50 \mathrm{~m}$ and $100 \mathrm{~m}$ away in this study signified reduction in impacts of anthropogenic activities as occasioned by activities at the auto-mechanic workshop clusters (Table 1). The existence plants whose roots deeply penetrated into varying soil depths and which must have been receiving nourishment from SOM and other beneficial elements in soils of the study area must have also significantly influenced the trend observed in this study (Table 1). 


\section{CONCLUSION}

Results of analyses carried out on the physicochemical parameters of soils at auto-mechanic workshop clusters and a control site in Yenagoa Metropolis for parameters like $\mathrm{pH}$, conductivity, nitrate, phosphate, soil organic matter, calcium, magnesium, sodium, potassium, CEC and THC were observed for the most part to follow the DistanceDecay Model as they in most instances showed higher levels at the top soils $(0-15 \mathrm{~cm})$ and decreased steadily through the soil profile $(15-30 \mathrm{~cm} \& 30-45 \mathrm{~cm})$ or showed higher levels at the reference points $(0 \mathrm{~m})$ and decreased with increasing distances $(50 \mathrm{~m} \& 100 \mathrm{~m})$, depending on influencing factors.

Thus, it could be safely stated that the operational presence of auto-mechanic workshop clusters in soils of the study area did impact the levels of soil physicochemical parameters within closer vicinities e.g. topsoils $(0-15 \mathrm{~cm})$ and reference points $(0 \mathrm{~m})$ more significantly than soils farther away from their vicinities. This could have serious soil and environmental effects as it could affect mobility of heavy metals, enhance heavy metal food contamination as well as generally affect food productivity.

\section{REFERENCES}

[1]. H.M.J. Abdul, A.I. Obaidy, A.M. Athmar and A.I. Mashhadi "Heavy metal contamination in urban soils within Baghdad city, Iraq," $J$. Environ. Protection, vol. 4, pp. 72-82, 2013.

[2]. O.A. Adewoyin, A.T. Hassan and A.A. Aladesida, "The impacts of auto-mechanic workshops on soil and ground water in Ibadan metropolis", African Journal of Environmental Science and Technology, vol. 7, no. 9, pp. 891-898, 2016.

[3]. K.D.T. Agusomu "Map of Yenagoa", In: O. Amukali, (2019) Effects of wastes from auto-mechanic workshops on concentrations of heavy metals in soils and plants in Yenagoa metropolis, Nigeria. A PhD dissertation submitted to the Post Graduate School of Niger Delta University, Amassoma, Bayelsa state, Nigeria, 278p, 2005.

[4]. J.C. Akan, S.I. Audu, Z. Mohammed and V.O. Ogugbuaja, "Assessment of heavy metals, $\mathrm{pH}$, organic matter and organic carbon in roadside soils in Makurdi metropolis, Benue state, Nigeria", $J$. Environ. Pro,. vol. 4, no. 6, pp. 1-11, 2013.

[5]. O.D. Akinyemi, J.A. Olowofela, O.O. Akinlade, and O.O. Akande, "Thermal conductivity of soils with heavy metal concentrations from the Niger Delta region of Nigeria", Journal of Zhejiang University Science vol. B 7, no. 8, pp. 615-618, 2006.

[6]. B.M.W. Amos-Tautau, A.O. Onigbinde and D. Ere, "Assessment of some heavy metals and

physicochemical properties in surface soils of municipal open waste Dumpsite in Yenagoa, Nigeria", African Journal of Environmental Science and Technology, vol. 8, no. 1, pp. 41-47, 2014.

[7]. O. Amukali, "Effects of wastes from auto-mechanic workshops on concentrations of heavy metals in soils and plants in Yenagoa metropolis, Nigeria", A PhD dissertation submitted to the Post Graduate School of Niger Delta University, Amassoma, Bayelsa state, Nigeria, p. 278, 2019.

[8]. P.A. Bariweni and O. Amukali, "Wetland cover changes in Yenagoa metropolis, Niger Delta, Nigeria", Journal of Post Graduate School of University of Port Harcourt, vol. 2, pp. 1-7, 2017.

[9]. P.A. Bariweni, W.L. Izonfuo and E.N. Amadi, "Domestic waste levels and assessment of their current management strategies in Yenagoa metropolis. Global Journal of Environmental Sciences, vol. 1, no. 1, pp. 15-19, 2002.

[10]. K. Banger, G.S. Toor, T.Chirenje and L. Ma, "Polycyclic aromatic hydrocarbons in urban soils of different land uses in Miama, Florida", Soil and Sediment Contamination. vol. 19, pp. 231-243, 2010.

[11]. G.J. Bouyoucos, C.M. Griffin and D.J. Briggs, "Particle size analysis: graphical interpretation of hydrometer readings and test methods", Soil Science, vol. 24, pp. 1-16, 1974.

[12]. L.I. Bukar, S. Stephen, S.S. Hati, G.A. Dimari and T.M. Muhammad, "Study of vertical migration of heavy metals in dumpsites soil", ARPN Journal of Science and Technology, vol. 2, no. 2, pp. 50-61, 2012.
[13]. N.C. Brady and R.R. Weil, "The Nature and Properties of Soils" 14th Edition, Pearson

Education, Inc., Singapore, 2000.

[14]. G. Brummer and U. Herms, In B. Ulrich and J. Pankrath (ed.), Effects of accumulation of air pollutants in forest ecosystems, Reidel Publishing Company, pp. 233-243, 1982.

[15]. DPR-EGASPIN, "Environmental guidelines and standards for the petroleum industry in Nigeria", Department of Petroleum, Lagos, Nigeria, p.234, 2002.

[16]. Federal Republic of Nigeria Gazzete, “Gazzete,” Abuja, Nigeria, 2007.

[17]. A.S. Hornby, S. Wehmeier and M. Ashby, "Oxford advanced learner's dictionary of current

English,"' 6th Edition, Oxford University Press, Oxford. p.1208, 2000.

[18]. R.A. Hoshmand, "Design of Experiments for Agriculture and the Natural Sciences," CRC Press, Boca Raton, Florida. p.145, 2016.

[19]. M.M. Lassat, "Phytoremediation of toxic metals: A review of biological mechanisms", J. Environ. Qual. Vol. 31, pp. 109 - 120, 2002.

[20]. C.J. Myung, "Heavy metal concentrations in soils and factors affecting metal uptake by plants in the vicinity of a Korean, CU-W mine", Sensors, vol. 8, pp. 2413-2423, 2008.

[21]. L. Ndiokwere and V.P. Guinn "Determination of some toxic trace metals in Nigeria: River and harbour water samples", NAAA J.Radio.Anal.Chem, vol. 71, no. 1, pp.147-151, 1983.

[22]. J.C. Nekola and P.S. White, "The distance decay of similarity in biogeography and ecology", Journal of Biogeography, vol. 26, pp.867-878, 1999.

[23]. Obafemi and Omiunu (2014)

[24]. O.O. Olayinka and O.H. Adedeji, "Concentration of heavy metals in the soils near some mechanic villages in Abeokuta metropolis, Ogun state, Nigeria", J. Advan. Chem, vol. 8, no.3, pp. 1667-1679, 2014.

[25]. A.A. Pam, R. Sha'Ato and J.O. Offem, "Evaluation of heavy metals in soils around automechanic workshop clusters in Gboko and Makurdi, Central Nigeria', J.Environ.Chem. Ecotoxic, vol 5, no. 11, pp. 298-306, 2013.

[26]. M. Radojevic and V.N. Bashkin, "Practical Environmental Analysis" $2^{\text {nd }}$ Edition, RSC Publishing, UK. pp.147-170, 2006.

[27]. L. Ruili, C. Minwei, and Y.Q. Guo, "Distribution, fraction and ecological assessment of heavy metals in sediment-plant system in mangrove forest, South China sea", PLOS ONE, vol. 10, no. 1371, pp. 1-15, 2016.

[28]. Shell Petroleum Development Company, "Final report of the environmental impact assessment (EIA) of Rumuekpe (OML 22) and Etelebou (OML 28) 3D seismic survey." SPDC Press, Portharcourt. p.393, 2006

[29]. USEPA, "Soil screening guidance: Technical background document", USEPA Rep. 540/R-95/128, US Gov. Print. Office, Washington, DC., p.121, 1996.

[30]. Wikipedia, "Yenagoa". http://en.wikipedia.org, Downloaded 18/10/2014, 2014.

[31]. J. Yang, Z. Ma, Z. Yel, X. Guo and R. Qin, "Heavy metal (Pb, Zn) uptake and chemical changes in rhizosphere soils of four wetland plants with different radial oxygen loss", J. Environ. Sci, vol.22, pp. 690-702, 2010.



O. Amukali

Senior Researcher in Environmental Management, Toxicology and Waste Management. He holds a B.Sc. (Hons) in Botany from Ambrose Alli University, Ekpoma, Nigeria. He also has an M.Sc. in Environmental Management from University of Maiduguri, Maiduguri, Nigeria; Post Graduate Diploma in Education from Kashim Ibrahim College of Education, Maiduguri, Nigeria; Post Graduate Diploma in Public Administration from University of Mkar, Nigeria; and PhD in Environmental Management and Toxicology, Niger Delta University, Amassoma, Nigeria.



\section{P.A. Bariweni}

Associate Professor in the Department of Marine Environment and Pollution Control in Nigeria Maritime University, Okerenkoko, Delta State, Nigeria. He's a specialist in Pollution Studies, Toxicology and Waste Management. He has a B.Sc. in Geography from University of Ibadan, Nigeria. He also has a Post Graduate Diploma in Education from University of Portharcourt, Nigeria; M.Phil in 
European Journal ofBiology and Biotechnology www.ejbio.org

Environmental Management from Rivers State University of Science and Technology, Nigeria and PhD in Environmental Management from Rivers State University of Science and technology, Nigeria. 